Jurnal Sistem Informasi (Journal of Information Systems). 1/13 (2017), 38-48

DOI: http://dx.doi.org/10.21609/jsi.v13i1.465

\title{
TANTANGAN DAN HAMBATAN IMPLEMENTASI PRODUK UANG ELEKTRONIK DI INDONESIA: STUDI KASUS PT XYZ
}

\author{
Kirana Widyastuti, Putu Wuri Handayani, dan Iik Wilarso \\ Magister Teknologi Informasi, Fakultas Ilmu Komputer, Universitas Indonesia Jl. Salemba Raya No.4, \\ Jakarta, 10430, Indonesia \\ E-mail: kirana.widyastuti31@ui.ac.id
}

\begin{abstract}
E-commerce development in Indonesia has been increasing since more online shops are established. The development of e-commerce triggers the use of e-payment as a payment instrument in online shops. $\mathrm{XYZ}$ company as one of the payment solution provider in Indonesia developed an electronic money product named M e-money. By the end of 2014, M e-money users had only reached the number of 1776 while the number of users targeted in the business plan was 142616. This research is intended to identify the barriers and challenges XYZ company faces in the implementation of M e-money. Data was collected through questionairres and interviews. The survey respondents consisted of $125 \mathrm{Me}$-money users where 93 of the respondents have used M e-money, and 32 of the respondents have never used $\mathrm{M}$ e-money. The qualitative data was collected through interviews to the $\mathrm{M}$ e-money team in $\mathrm{XYZ}$ company. Interviews were also conducted to 9 users of M e-money. The research concludes barriers and challenges faced by XYZ company in the implementation of M e-money. The barriers faced by the $\mathrm{M}$ $e$-money users are the limitation of merchants, limitation of access method, limitation of transaction channel, the cost of transaction, other e-money products existed, and socio-cultural factor. Barriers faced by the management are the lack of experience in B2C business and the difficulty of acquiring new $\mathrm{M}$ $e$-money users. These barriers leads to challenges faced by the company. The challenges faced by the company in the implementation of $\mathrm{M} e$-money are the high competition among similar products, the influence of substitute products, and high expectation from users to have a safe, convenience, and trusted e-money services.
\end{abstract}

Keywords: e-payment, e-money, challenges, barriers

\begin{abstract}
Abstrak
Perkembangan e-commerce di Indonesia semakin pesat dilihat dari banyaknya toko-toko online yang bermunculan. Hal ini membuka peluang bagi penggunaan jenis-jenis e-payment sebagai media pembayaran pada toko online. PT XYZ mengembangkan produk uang elektronik bernama uang elektronik $M$ sebagai salah satu solusi untuk sistem pembayaran dengan e-payment. Pada pelaksanaannya, perkembangan produk uang elektronik ini masih jauh dari target jumlah nasabah yang diharapkan yaitu baru mencapai 1776 dari target 142616 nasabah. Penelitian ini dilakukan untuk mengidentifikasi tantangan dan hambatan dalam implementasi produk uang elektronik PT XYZ. Objek penelitian ini adalah pengguna dan pengelola produk uang elektronik M. Penelitian dilakukan dengan menggunakan metode kuantitatif dan kualitatif. Pengumpulan data kuantitatif dilakukan melalui penyebaran kuesioner kepada nasabah uang elektronik M sebanyak 125 orang yang terdiri dari 93 nasabah yang pernah bertransaksi dan 32 nasabah yang belum pernah bertransaksi. Pengumpulan data kualitatif dilakukan melalui wawancara kepada ketua tim dan manajer pemasaran uang elektronik $\mathrm{M}$ serta kepada 9 orang nasabah uang elektronik M. Penelitian yang dilakukan memberikan kesimpulan bahwa hambatan yang dihadapi nasabah uang elektronik $M$ meliputi keterbatasan merchant, keterbatasan metode akses, keterbatasan channel transaksi, biaya transaksi, kompetitor produk sejenis, serta faktor sosial budaya yaitu kebiasaan menggunakan metode pembayaran selain uang elektronik. Hambatan yang dihadapi pengelola uang elektronik $M$ meliputi kurangnya pengalaman menjalankan model bisnis B2C, serta sulitnya mengakuisisi pelanggan baru. Tantangan yang dihadapi PT XYZ dalam pengembangan uang elektronik $M$ adalah tingkat kompetisi produk sejenis yang tinggi, adanya pengaruh barang substitusi serta tingginya ekspektasi nasabah untuk memperoleh layanan uang elektronik yang aman, nyaman, dan terpercaya.
\end{abstract}

Kata Kunci: e-payment, e-money, tantangan, hambatan 


\section{Latar Belakang}

Bank Indonesia mencanangkan program Gerakan Nasional Non Tunai pada tanggal 14 Agustus 2014. Gerakan ini dicanangkan dengan tujuan membentuk masyarakat yang lebih banyak menggunakan instrumen non tunai (Less Cash Society/LCS) dalam melakukan transaksi atas kegiatan ekonominya [1]. Salah satu upaya per-wujudan tujuan dari Gerakan Nasional Non Tunai adalah dengan mendukung dan mengembangkan uang elektronik sebagai instrumen pembayaran non tunai.

Uang elektronik sebagai instrumen pembayaran saat ini semakin banyak digunakan di Indonesia. Berdasarkan data statistik Bank Indonesia, hingga November 2013 jumlah uang elektronik yang beredar di Indonesia mencapai angka 286. 756.651 [2]. Jumlah ini telah mengalami peningkatan sebesar 52,94\% dari jumlah uang elektronik yang beredar hingga tahun 2012. Jumlah transaksi menggunakan uang elek-tronik di Indonesia pada bulan November 2013 adalah 12.326.415 transaksi. Rata-rata transaksi uang elektronik yang terjadi di Indonesia per bulan adalah 11.405.282 transaksi [2]. Hal ini menunjukkan penggunaan uang elektronik di Indonesia terus mengalami pertumbuhan.

Uang elektronik dapat digolongkan menjadi dua kelompok besar, yaitu uang elektronik berbasis server (online) dan uang elektronik berbasis chip (offline). Uang elektronik berbasis chip pada umumnya digunakan untuk transaksi yang ingin dilakukan dalam waktu singkat dan frekuensinya besar, contohnya transportasi. Sementara, uang elektronik berbasis server umumnya digunakan untuk transaksi pembayaran secara online melalui web browser. Hingga awal tahun 2015, jumlah penerbit uang elektronik yang telah mendapatkan izin dari Bank Indonesia adalah sebanyak 20 penerbit [3]. PT XYZ merupakan perusahaan yang bergerak dalam bidang keuangan khususnya layanan pembayaran elektronis. Melihat peluang yang ada dari perkembangan transaksi e-commerce, PT XYZ mengembangkan produk uang elektronik yang dinamakan Uang Elektronik M.

Produk uang elektronik $\mathrm{M}$ yang dikelola PT XYZ merupakan uang elektronik berbasis server. Artinya, nilai uang disimpan dalam suatu server yang dapat diakses oleh pemilik rekening uang elektronik untuk melakukan pembayaran secara online. Sebelum menjadi pengguna uang elektronik ini, perlu dilakukan pendaftaran nasabah untuk mendapatkan nomor rekening uang elektronik $\mathrm{M}$. Pengguna dapat mengisi uang elektronik $M$ dengan transfer melalui ATM maupun secara tunai di loket uang elektronik M. Uang elektronik ini dapat digunakan untuk melakukan pembayaran pada saat berbelanja di toko online yang bekerjasama dengan PT XYZ.
Pencapaian target bisnis uang elektronik $\mathrm{M}$ pada saat ini masih sangat rendah. Berdasarkan dokumen rencana bisnis M (PT XYZ, tidak dipublikasikan. 2011), awalnya ditargetkan nasabah uang elektronik M akan mencapai 142.616 orang pada akhir tahun 2014. Namun pada pelaksanaannya, jumlah nasabah uang elektronik $M$ hingga akhir tahun 2014 hanya mencapai 1.776 orang atau hanya 1,25\% dari target (PT XYZ, tidak dipublikasikan. 2014). Jumlah transaksi uang elektronik $M$ sejak tahun 2012 hingga akhir tahun 2014 adalah 2.220 transaksi (PT XYZ, tidak dipublikasikan. 2014). Apabila dibandingkan dengan transaksi uang elektronik di Indo-nesia yang mencapai angka rata-rata 11.405.282 transaksi per bulan, jumlah tersebut sangatlah kecil. Pencapaian target bisnis yang masih jauh dari rencana awal serta jumlah transaksi yang masih sangat sedikit merupakan permasalahan pada implementasi bisnis produk uang elektronik $M$ yang belum diidentifikasi penyebabnya.

Jumlah penelitian mengenai tantangan dan hambatan produk uang elektronik masih terbatas. Salah satu contoh kasus yang ditemui adalah penelitian mengenai suatu jenis instrumen e-payment di Ghana. Kumaga [4], Haruna [5], dan Agyeiwaah [6] telah melakukan penelitian mengenai tantangan yang dihadapi $e$-zwich, suatu alat pembayaran elektronik menggunakan smart card yang dikembangkan di Ghana. Penelitian dilakukan menggunakan metode survei kepada pengguna layanan e-zwich. Penelitian ini menemukan bahwa tantangan dalam pengembangan suatu metode pembayaran elektronik meliputi faktor kepercayaan pengguna, ketersediaan infrastruktur, keamanan sistem, serta faktor sosial budaya.

Belum tercapainya target bisnis uang elektronik M serta masih terbatasnya penelitian terkait uang elektronik merupakan permasalahan yang melatarbelakangi penelitian ini. Paper ini membahas penelitian yang telah dilakukan mengenai tantangan dan hambatan yang dihadapi PT XYZ dalam mengembangkan produk uang elektronik $\mathrm{M}$. Penelitian didasarkan pada permasalahan yang telah dikemukakan serta beberapa penelitian terkait. Struktur paper ini diawali dengan pemaparan masalah dan latar belakang, tinjauan pustaka, metodologi penelitian, kemudian dilanjutkan dengan hasil dan pembahasan, kesimpulan dan saran. Tantangan dan hambatan produk elektronik $M$ yang diidentifikasi dapat menjadi bahan evaluasi bagi PT XYZ untuk perencanaan strategi bisnis produk uang elektronik M selanjutnya.

\section{E-commerce}

Menurut [7], e-commerce adalah proses membeli, menjual, memindahkan, atau menukarkan produk, 
TABEL 1

PRODUK E-MONEY YANG TERSEDIA PADA WEBSITE E-COMMERCE POPULER DI INDONESIA

\begin{tabular}{lll}
\hline \multicolumn{1}{c}{ Nama } & $\begin{array}{c}\text { Rank- } \\
\text { ing }\end{array}$ & \multicolumn{1}{c}{ Produk E-Money yang Tersedia } \\
\hline Tokopedia & 34 & $\begin{array}{l}\text { Mandiri e-cash } \\
\text { Elevenia }\end{array}$ \\
Traveloka & 84 & $\begin{array}{l}\text { Telkomsel T-Cash } \\
\text { Mandiri e-cash }\end{array}$ \\
Aliexpress & 90 & DOKU Wallet \\
Bhinneka & 93 & $\begin{array}{l}\text { Mandiri e-cash, Telkomsel T-cash, } \\
\text { XL Tunai }\end{array}$ \\
\hline
\end{tabular}

jasa, atau informasi melalui jaringan komputer termasuk Internet. E-commerce dapat dikategorikan berdasarkan sifat transaksinya atau interaksi yang terjadi antara penjual dan pembeli. Klasifikasi $e$ commerce berdasarkan sifat transaksi atau interaksinya adalah sebagai berikut [7]: Business-to-Business (B2B), Business-to-Consumer (B2C), Business-to-Business-to-Consumer (B2B2C), Consumer-to-Business (C2B), Mobile Commerce, dan Intrabusiness E-commerce.

\section{E-payment}

Menurut [8], e-payment dapat didefinisikan sebagai semua pembayaran yang dilakukan kepada bisnis, bank, atau layanan publik dari masyarakat atau bisnis, dan dieksekusi melalui jaringan telekomunikasi atau jaringan elektronik menggunakan teknologi modern. Berdasarkan definisi ini, pembayaran elektronis yang dimaksud adalah pembayaran yang dilakukan sendiri oleh pelaku baik perorangan maupun bisnis, tanpa intervensi dari orang lain. Oleh karena itu, pembayaran dilakukan dari jarak jauh, tanpa kehadiran fisik dari pembeli sehingga tidak melibatkan uang kertas. Masih menurut [8], sistem pembayaran elektronis secara umum dapat diklasifikasikan ke dalam empat kategori utama, yaitu: online credit card, electronic cash, electronic cheque, dan smart cards. Sahut [9] membagi jenis-jenis sistem pembayaran elektronis ke dalam enam kategori. Kategori tersebut yaitu: card based systems, electronic money, e-mail payments, electronic checks, other electronic solutions, dan mobile payments.

\section{E-money}

Berdasarkan definisi European Central Bank, $e$ money merupakan sebuah nilai uang yang disimpan secara elektronik ke dalam sebuah alat yang dapat digunakan untuk melakukan pembayaran kepada pihak selain penerbit uang tanpa perlu melibatkan akun bank dalam transaksi, dan bertindak sebagai instrumen yang bersifat prabayar. Menurut Fung et.al [10], e-money merupakan nilai uang yang disimpan secara elektronik ke dalam alat seperti kartu chip atau hard drive di dalam komputer atau server, direpresentasikan dengan klaim pada penerbit, dan diterbitkan dengan sejumlah dana yang digunakan untuk melakukan transaksi pembayaran yang dilakukan kepada pihak selain penerbit uang elektronik.

Berdasarkan Peraturan BI nomor 11/12/PBI/ 2009 tentang uang elektronik [11], uang elektronik (electronic money) adalah alat pembayaran yang memenuhi unsur-unsur sebagai berikut:

a. diterbitkan atas dasar nilai uang yang disetor terlebih dahulu oleh pemegang kepada penerbit;

b. nilai uang disimpan secara elektronik dalam suatu media seperti server atau chip;

c. digunakan sebagai alat pembayaran kepada pedagang yang bukan merupakan penerbit uang elektronik tersebut; dan

d. nilai uang elektronik yang disetor oleh pemegang dan dikelola oleh penerbit bukan merupakan simpanan sebagaimana dimaksud dalam undang-undang yang mengatur mengenai perbankan.

\section{E-money di Indonesia}

Hingga tahun 2015, di Indonesia terdapat 20 penerbit uang elektronik yang sudah memiliki izin dari Bank Indonesia [3].

Berdasarkan daftar produk e-money pada Tabel 1, dapat disimpulkan bahwa produk uang elektronik M tidak tersedia pada website $e$-commerce populer di Indonesia. Kompetitor besar yang dihadapi produk uang elektronik M adalah Mandiri e-cash, XL Tunai, Indosat Dompetku, Telkomsel T-Cash, dan DOKU Wallet.

Terdapat 20 penerbit uang elektronik di Indonesia pada tahun 2015. Perbandingan ini dilakukan dengan produk uang elektronik DOKU Wallet, Telkomsel T-cash, Mandiri e-cash, XL Tunai, dan Indosat Dompetku. Faktor yang dijadikan bahan perbandingan adalah jumlah merchant, cara pendaftaran, cara top up, jenis pelanggan, saldo maksimum, serta fitur tambahan yang dimiliki. Perbandingan produk uang elektronik $M$ dengan produk sejenis di Indonesia dapat dilihat pada Tabel 2.

Berdasarkan perbandingan produk uang elektronik pada Tabel 2, dapat dilihat bahwa produk uang elektronik M memiliki jumlah merchant paling sedikit yaitu 11 merchant. Selain itu, jenis merchant yang dapat menerima pembayaran menggunakan uang elektronik $M$ hanya merchant yang bersifat online. Apabila dibandingkan dengan produk uang elektronik lainnya, produk uang elektronik $\mathrm{M}$ masih memiliki kekurangan dalam jumlah merchant. Selain itu, pilihan dalam mekanisme transaksi menggunakan uang elektronik M masih 
TABEL 2

\begin{tabular}{|c|c|c|c|c|c|c|}
\hline Keterangan & $\begin{array}{c}\text { Uang El- } \\
\text { ektronik M }\end{array}$ & DOKU Wallet & $\begin{array}{c}\text { Mandiri e- } \\
\text { cash }\end{array}$ & $\begin{array}{c}\text { Telkomsel T- } \\
\text { cash }\end{array}$ & XL Tunai & $\begin{array}{c}\text { Indosat } \\
\text { Dompetku }\end{array}$ \\
\hline Tahun & 2013 & 2011 & 2014 & 2007 & 2012 & 2013 \\
\hline $\begin{array}{l}\text { Jumlah } \\
\text { Merchant }\end{array}$ & 11 & 178 & 62 & 46 & 59 & 29 \\
\hline $\begin{array}{l}\text { Jenis } \\
\text { Merchant }\end{array}$ & Online & $\begin{array}{l}\text { Online \& } \\
\text { Offline }\end{array}$ & $\begin{array}{l}\text { Online \& } \\
\text { Offline }\end{array}$ & $\begin{array}{l}\text { Online \& } \\
\text { Offline }\end{array}$ & $\begin{array}{l}\text { Online \& } \\
\text { Offline }\end{array}$ & $\begin{array}{l}\text { Online \& } \\
\text { Offline }\end{array}$ \\
\hline $\begin{array}{l}\text { Cara } \\
\text { mendaftar } \\
\text { sebagai } \\
\text { nasabah }\end{array}$ & $\begin{array}{l}\text { Online melalui } \\
\text { website uang } \\
\text { elektronik M }\end{array}$ & $\begin{array}{l}\text { Online melalui } \\
\text { website Doku } \\
\text { Wallet }\end{array}$ & $\begin{array}{l}\text { Melalui } \\
\text { ponsel } \\
\text { pengguna }\end{array}$ & $\begin{array}{l}\text { Melalui ponsel } \\
\text { dengan nomor } \\
\text { telkomsel }\end{array}$ & $\begin{array}{l}\text { Melalui } \\
\text { ponsel } \\
\text { dengan } \\
\text { nomor XL }\end{array}$ & $\begin{array}{l}\text { Melalui posel } \\
\text { dengan nomor } \\
\text { Indosat }\end{array}$ \\
\hline Jenis & Reguler & Reguler & Unregistered & Basic Service & Non- & Unregistered \\
\hline Pelanggan & Premium & Premium & Registered & Full Service & $\begin{array}{l}\text { Register } \\
\text { Full Register }\end{array}$ & Registered \\
\hline Cara Top Up & $\begin{array}{l}\text { Transfer } \\
\text { melalui } \\
\text { jaringan ATM } \\
\text { antar bank } \\
\text { Melalui loket } \\
\text { top up }\end{array}$ & $\begin{array}{l}\text { ATM BNI } \\
\text { SMS Banking } \\
\text { BNI } \\
\text { Trannsfer } \\
\text { Convenience } \\
\text { Store }\end{array}$ & $\begin{array}{l}\text { ATM Mandiri } \\
\text { SMS Banking } \\
\text { Mandiri } \\
\text { Mandiri } \\
\text { ClickPay } \\
\text { Transfer antar } \\
\text { bank }\end{array}$ & $\begin{array}{l}\text { Grapari } \\
\text { Indomaret } \\
\text { Transfer antar } \\
\text { bank }\end{array}$ & $\begin{array}{l}\text { Transfer } \\
\text { antar bank } \\
\text { Toko Agen } \\
\text { Pulsa } \\
\text { Alfamart } \\
\text { XL Center }\end{array}$ & $\begin{array}{l}\text { Transfer } \\
\text { Setor Tunai ke } \\
\text { kantor cabang }\end{array}$ \\
\hline
\end{tabular}

terbatas yaitu hanya dapat digunakan untuk transaksi pada merchant yang memiliki website sebagai media transaksi. Produk uang elektronik lain telah mengembangkan uang elektroniknya untuk dapat digunakan bertransaksi pada kasir toko secara offline. Pilihan cara isi saldo rekening yang ditawarkan produk uang elektronik $\mathrm{M}$ juga paling sedikit dibandingkan produk uang elektronik lainnya.

\section{Tantangan dan Hambatan dalam E-payment}

Berdasarkan studi literatur, ditemukan 6 variabel utama yang merupakan faktor hambatan dan tantangan dalam e-payment. Variabel tersebut adalah penerimaan pengguna, keamanan, keterse-diaan infrastruktur, faktor sosial budaya, kenyama-nan penggunaan, dan preferensi pengguna. Varia-bel ini diperoleh dari penelitian terdahulu yang terkait dengan implementasi instrumen e-payment di negara berkembang. Pemilihan variabel yang digunakan dalam penelitian ini disesuaikan dengan kondisi perkembangan uang elektronik di Indonesia. Ringkasan variabel serta referensi yang melandasinya dapat dilihat pada Tabel 3 .

\section{Penerimaan Pengguna}

Variabel penerimaan pengguna ditemukan oleh [4] dalam penelitiannya. Menurut Kumaga [4], penerimaan pengguna (acceptance) dipengaruhi kecenderungan seseorang untuk menggunakan uang elektronik dibandingkan uang tunai. Faktor penerimaan pengguna dalam implementasi produk uang elektronik M penting karena salah satu target bisnis uang elektronik $\mathrm{M}$ adalah peningkatan jumlah nasabah dari tahun ke tahun. Apabila penerimaan pengguna terhadap uang elektronik semakin baik, maka peluang PT XYZ untuk mencapai target peningkatan jumlah nasabah juga semakin besar.

\section{Keamanan}

Variabel keamanan digunakan oleh Kumaga [4] dalam mengidentifikasi tantangan yang terjadi pada sebuah sistem e-payment di Ghana. Menurut Kumaga [4], faktor keamanan merupakan salah satu tantangan dalam pengembangan e-payment secara umum. Variabel keamanan juga digunakan dalam studi kasus ini. Melalui informasi yang diperoleh mengenai ekspektasi nasabah terhadap keamanan sistem uang elektronik, dapat ditentukan apakah tujuan pengembangan produk uang elektronik $M$ terkait dengan keamanan sudah sesuai dengan harapan nasabah. Selain itu, tingginya nilai dari variabel keamanan ini juga dapat menjadi indikator bahwa faktor keamanan merupakan salah satu tantangan yang dihadapi PT XYZ dalam pengembangan produk uang elektronik $\mathrm{M}$.

\section{Ketersediaan Infrastruktur}

Variabel ketersediaan infrastruktur digunakan oleh Kumaga [4] dalam penelitiannya terkait tantangan implementasi uang elektronik di Ghana. Selain itu, menurut Haruna [6], faktor ketersediaan infrastruktur yang meliputi keandalan jaringan, kecepatan transaksi, serta keandalan sistem merupakan tantangan dalam pengembangan uang elektronik. Agyeiwaah [5] juga menggunakan variabel ketersediaan infrastruktur dalam survei untuk penelitiannya. Tingkat ketersediaan infrastruktur menurut pengguna uang elektronik $M$ penting untuk diketahui karena salah satu komitmen PT XYZ dalam pengembangan uang elektronik $M$ adalah menyediakan alat pembayaran yang terpercaya (PT XYZ, tidak dipublikasikan. 2012). 
TABEL 3

\begin{tabular}{|c|c|c|}
\hline Variabel & Keterangan & Referensi \\
\hline Penerimaan Pengguna & $\begin{array}{l}\text { Kecenderungan pengguna memakai uang elektronik } \\
\text { dibandingkan uang tunai } \\
\text { Pengetahuan pengguna tentang cara penggunaan uang } \\
\text { elektronik } \\
\text { Kepercayaan pengguna terhadap layanan e-payment }\end{array}$ & Kumaga (2010) \\
\hline Keamanan & Resiko penyalahgunaan akun & Kumaga (2010) \\
\hline $\begin{array}{l}\text { Ketersediaan } \\
\text { Infrastruktur }\end{array}$ & $\begin{array}{l}\text { Jaringan internet yang selalu tersedia } \\
\text { Sistem yang selalu tersedia } \\
\text { Transaksi diproses dengan cepat } \\
\text { Jaringan internet yang cepat }\end{array}$ & $\begin{array}{l}\text { Kumaga (2010), Issahaku (2012), dan } \\
\text { Agyeiwaah (2014) }\end{array}$ \\
\hline Faktor Sosial Budaya & $\begin{array}{l}\text { Tingkat unbanked population } \\
\text { Tingkat adopsi e-payment }\end{array}$ & Kumaga (2010) \\
\hline $\begin{array}{l}\text { Kenyamanan } \\
\text { Penggunaan }\end{array}$ & $\begin{array}{l}\text { Kenyamanan penggunaan } \\
\text { Kesesuaian dengan harapan pengguna } \\
\text { Kemudahan akses } \\
\text { Kemudahan proses top up } \\
\text { Kemudahan proses pendaftaran }\end{array}$ & Phuong Nam (2014) dan Sahut (2008) \\
\hline Kompetitor & Preferensi penggunaan merek produk uang elektronik & Sahut (2008) \\
\hline
\end{tabular}

Sosial Budaya

Menurut Kumaga [4], salah satu faktor yang menjadi tantangan dalam pengembangan uang elektronik adalah faktor sosial budaya masyarakat setempat. Faktor sosial budaya meliputi jumlah penduduk yang belum memiliki akses menuju layanan perbankan. Selain itu, faktor sosial budaya juga berkaitan dengan tingkat adopsi masyarakat terhadap layanan uang elektronik.

\section{Kenyamanan Penggunaan}

Menurut Dao [12], salah satu faktor yang menjadi tantangan dalam pengembangan e-banking adalah ekspektasi nasabah. Selain itu menurut Sahut [13], kenyamanan penggunaan merupakan salah satu faktor kesuksesan solusi pembayaran elektronis. Kenyamanan penggunaan dapat menarik minat pengguna terhadap layanan e-payment [13]. Salah satu tujuan PT XYZ mengembangkan uang elektronik $\mathrm{M}$ adalah menyediakan alat pembayaran yang praktis. Informasi mengenai penilaian pengguna uang elektronik $\mathrm{M}$ terhadap kenyamanan penggunaan uang elektronik $M$ dapat menjadi bahan evaluasi terhadap pencapaian tujuan pengembangan produk uang elektronik $\mathrm{M}$.

\section{Preferensi Pengguna}

Menurut Sahut [13], salah satu tantangan dalam pengembangan $e$-money adalah tantangan kompetitif. Faktor kompetitif ini dipengaruhi dengan banyaknya institusi lain yang juga menjadi penerbit uang elektronik. Apabila dilihat dari sisi pengguna, maka tantangan yang dihadapi oleh penerbit uang elektronik adalah preferensi pengguna dalam memilih produk uang elektronik ter- tentu. Variabel kompetitif atau preferensi penggunaan dipilih untuk digunakan dalam penelitian ini karena dalam kasus produk uang elektronik $\mathrm{M}$ di Indonesia, terdapat 20 kompetitor produk sejenis.

\section{Metode Penelitian}

\section{Populasi, Sampel, dan Prosedur Pengumpulan Data}

Penelitiaan ini dilakukan dengan menggunakan metode kuantitatif dan kualitatif. Metode kuantitatif digunakan untuk mengukur respon nasabah terhadap faktor tantangan uang elektronik dengan menggunakan kuesioner. Kuesioner diberikan kepada nasabah uang elektronik $M$ dengan dua kategori. Kategori pertama adalah nasabah yang sudah pernah bertransaksi menggunakan uang elektronik M. Kategori kedua adalah nasabah yang belum pernah bertransaksi menggunakan uang elektronik $\mathrm{M}$ namun pernah menggunakan uang elektronik jenis lainnya. Jenis kuesioner yang disebarkan adalah kuesioner online. Tautan kuesioner disebarkan melalui e-mail kepada 400 orang nasabah uang elektronik $\mathrm{M}$.

Metode kualitatif digunakan untuk menggali secara lebih mendalam tantangan dan hambatan yang dihadapi pengguna dan pengelola uang elektronik M. Wawancara terhadap pengelola dilakukan kepada dua orang narasumber yaitu ketua tim produk uang elektronik $\mathrm{M}$ dan manajer pemasaran uang elektronik M. Wawancara terhadap nasabah uang elektronik $\mathrm{M}$ dilakukan kepada 9 orang narasumber. Narasumber dalam penelitian ini terdiri dari 4 orang wanita dan 5 orang pria. 


\section{Instrumen Penelitian}

Variabel yang digunakan dalam penelitian ini ada 6 yaitu Penerimaan Pengguna, Keamanan, Ketersediaan Infrastruktur, Isu Sosial Budaya, Kenyamanan Penggunaan, dan Kompetitor. Terdapat 5 penelitian terkait yang melandasi pemilihan variabel penelitian. Penelitian tersebut adalah penelitian yang dilakukan Kumaga [4], Haruna [6], Agyeiwaah [5], Dao [12], dan Sahut [13].

\section{Hasil dan Pembahasan}

\section{Demografi Responden}

Kuesioner penelitian ditujukan kepada nasabah uang elektronik M. Data nasabah uang elektronik M diperoleh dari PT XYZ. Respon terhadap kuesioner diperoleh dengan cara mengirimkan email tautan kuesioner kepada 400 orang nasabah uang elektronik M. Jumlah kuesioner yang diisi oleh responden adalah sebanyak 125 orang. Demografi responden yang mengisi kuesioner penelitian dapat dilihat pada Tabel 4.

\section{Hasil Penyebaran Kuesioner}

Hasil penyebaran kuesioner diolah dan dianalisis berdasarkan masing-masing variabel yang telah ditentukan sebelumnya. Tabel 5 menunjukkan hasil pengolahan data kuesioner dari 6 variabel yang digunakan yaitu penerimaan pengguna, keamanan, ketersediaan jaringan, faktor sosial budaya, kenyamanan penggunaan, serta preferensi penggunaan. Variabel pertama yang dianalisis adalah variabel penerimaan pengguna. Variabel penerimaan pengguna menilai tingkat penerimaan pengguna terhadap uang elektronik secara umum. Hasil survei terhadap variabel penerimaan pengguna pada Tabel 2 menunjukkan nilai rata-rata 4.83 , yang berarti bahwa responden memiliki tingkat kepercayaan yang baik terhadap sistem pembayaran menggunakan uang elektronik.

Variabel berikutnya adalah variabel keamanan yang mengukur tingkat perhatian responden terhadap tingkat keamanan uang elektronik $\mathrm{M}$. Hasil survei yang diberikan responden terhadap variabel ini dapat dilihat pada Tabel 5 . Nilai ratarata yang diberikan responden terhadap variabel keamanan adalah 5,53. Hal ini menunjukkan bahwa ekspektasi atau harapan responden terhadap tingkat keamanan yang dimiliki uang elektronik M termasuk ke dalam kategori sangat baik.

Variabel Ketersediaan Infrastruktur digunakan untuk menilai tingkat ketersediaan dari layanan uang elektronik $M$. Variabel ini terdiri dari empat pertanyaan yang meliputi ketersediaan jaringan, kecepatan proses layanan, ketersediaan la- yanan, dan keterjangkauan biaya layanan. Hasil survei terkait variabel ketersediaan infrastruktur dapat dilihat pada Tabel 5. Nilai variabel ketersediaan infrastruktur dari seluruh responden adalah 4,43. Berdasarkan penilaian ini, dapat disimpulkan bahwa tingkat ketersediaan infrastruktur uang elektronik M termasuk ke dalam kategori baik.

Variabel faktor sosial dan budaya digunakan untuk melihat bagaimana persepsi nasabah terhadap uang elektronik $M$ jika dikaitkan dengan beberapa faktor sosial. Faktor sosial budaya tersebut misalnya pengaruh kepemilikan rekening bank terhadap kemudahan bertransaksi online, serta pemenuhan kebutuhan transaksi pembayaran online melalui uang elektronik M. Penilaian seluruh responden terhadap variabel faktor sosial dan budaya adalah 4.54 .

Variabel kenyamanan penggunaan digunakan untuk menilai tingkat kenyamanan yang diberikan oleh produk uang elektronik M kepada nasabahnya. Variabel ini terdiri dari lima pertanyaan. Pertanyaan tersebut meliputi kenyamanan penggunaan, kesesuaian layanan dengan harapan, kemudahan akses, kemudahan proses top-up, dan kemudahan transaksi dengan uang elektronik M. Nilai rata-rata untuk variabel kenyamanan penggunaan yang diberikan oleh keseluruhan responden adalah 4,05. Hal ini menunjukkan b ahwa responden beranggap-an bahwa tingkat kenyamanan penggunaan uang elektronik M sudah baik.

Variabel preferensi penggunaan merupakan variabel yang digunakan untuk melihat preferensi Pertanyaan yang digunakan dalam variabel ini adalah apakah responden lebih memilih produk uang elektronik M dibandingkan produk uang elektronik lainnya. Nilai rata-rata yang diberikan oleh keseluruhan responden untuk indikator ini adalah 3,37.

TABEL 4

\begin{tabular}{|c|c|c|}
\hline \multicolumn{3}{|c|}{ DEMOGRAFI RESPONDEN PENELITIAN } \\
\hline Demografi & Atribut & Persentase \\
\hline \multirow[t]{2}{*}{ Jenis Kelamin } & Pria & $65 \%$ \\
\hline & Wanita & $35 \%$ \\
\hline \multirow[t]{4}{*}{ Pendidikan Terakhir } & SMA & $1 \%$ \\
\hline & D3 & $6 \%$ \\
\hline & $\mathrm{S} 1$ & $14 \%$ \\
\hline & $\mathrm{S} 2$ & $79 \%$ \\
\hline Penghasilan per & $<\operatorname{Rp} 2,5$ juta & $3 \%$ \\
\hline \multirow[t]{6}{*}{ Bulan } & $\operatorname{Rp} 2,5-\operatorname{Rp} 5$ juta & $17 \%$ \\
\hline & $\operatorname{Rp} 5-\operatorname{Rp} 7,5$ & $48 \%$ \\
\hline & juta & $14 \%$ \\
\hline & $\mathrm{Rp} 7,5-\mathrm{Rp} 10$ & $18 \%$ \\
\hline & juta & \\
\hline & $>$ Rp 10 juta & \\
\hline \multirow{5}{*}{$\begin{array}{l}\text { Penggunaan } \mathrm{M} e- \\
\text { money }\end{array}$} & 0 kali (tidak & $26 \%$ \\
\hline & pernah) & $47 \%$ \\
\hline & $1-2$ kali & $20 \%$ \\
\hline & $3-4$ kali & $3 \%$ \\
\hline & $\begin{array}{l}5-6 \text { kali } \\
>6 \text { kali }\end{array}$ & $4 \%$ \\
\hline \multirow[t]{3}{*}{ Kepemilikan e-money } & Hanya M e- & $38 \%$ \\
\hline & money & $62 \%$ \\
\hline & Punya produk lain & \\
\hline
\end{tabular}


TABEL 5

Hasil Pengolahan Data Kuesioner

\begin{tabular}{|c|c|c|c|}
\hline Indikator & Pertanyaan & Rata-rata & Standar Deviasi \\
\hline & Penerimaan Pengguna & & \\
\hline PP1 & Saya memilih menggunakan uang elektronik dibandingkan uang tunai & 4.45 & 0.94 \\
\hline PP2 & Saya mengetahui cara menggunakan uang elektronik untuk berbelanja & 5.22 & 0.69 \\
\hline \multirow[t]{3}{*}{ PP3 } & Saya percaya pada system pembayaran menggunakan uang elektronik & 4.83 & 0.87 \\
\hline & Rata-rata & 4.83 & \\
\hline & Keamanan & & \\
\hline \multirow[t]{3}{*}{ K1 } & Uang elektronik $\mathrm{M}$ harus dilengkapi sistem keamanan yang baik & 5.53 & 0.76 \\
\hline & Rata-rata & 5.53 & \\
\hline & Ketersediaan Jaringan & & \\
\hline KI1 & Jaringan uang elektronik M selalu tersedia & 4.42 & 1.09 \\
\hline KI2 & Pembayaran dengan uang elektronik M diproses dengan cepat & 4.42 & 1.04 \\
\hline $\mathrm{K} 33$ & Fitur pembayaran dengan uang elektronik M selalu dapat diakses & 4.36 & 1.01 \\
\hline \multirow[t]{3}{*}{ KI4 } & Layanan uang elektronik $\mathrm{M}$ dapat digunakan dengan biaya terjangkau & 4.50 & 1.04 \\
\hline & Rata-rata & 4.43 & \\
\hline & Faktor Sosial \& Budaya & & \\
\hline SB1 & Dengan memiliki rekening bank, transaksi online menjadi lebih mudah & 5.23 & 0.66 \\
\hline \multirow[t]{3}{*}{ SB2 } & Fitur yang dimiliki $\mathrm{M}$ e-money memenuhi kebutuhan saya bertransaksi & 3.83 & 1.22 \\
\hline & Rata-rata & 4.54 & \\
\hline & Kenyamanan Penggunaan & & \\
\hline KP1 & Uang elektronik M nyaman digunakan sebagai alat pembayaran & 4.18 & 1.02 \\
\hline KP2 & Layanan yang diberikan uang elektronik M sesuai harapan saya & 3.71 & 1.06 \\
\hline KP3 & Uang elektronik M dapat diakses dimanapun dan kapanpun & 4.00 & 1.14 \\
\hline KP4 & Proses top-up uang elektronik M mudah dilakukan & 3.97 & 1.14 \\
\hline \multirow[t]{3}{*}{ KP5 } & Proses pendaftaran akun uang elektronik M mudah dilakukan & 4.36 & 1 \\
\hline & Rata-rata & 4.05 & \\
\hline & Preferensi Penggunaan & & \\
\hline \multirow[t]{2}{*}{ PR1 } & Saya lebih memilih uang elektronik M dibandingkan produk lainnya & 3.37 & 1.12 \\
\hline & Rata-rata & 3.37 & \\
\hline
\end{tabular}

Hasil penilaian terhadap variabel ini menunjukkan bahwa preferensi penggunaan responden terhadap uang elektronik $\mathrm{M}$ dibandingkan uang elektronik lainnya cukup baik. nasabah dalam menggunakan uang elektronik $\mathrm{M}$.

Selain mengisi pertanyaan pilihan, responden juga diminta untuk menuliskan hambatan-hambatan yang dialami dalam penggunaan uang elektronik M. Berdasarkan hasil survei yang dilakukan, jawaban dari responden dapat disimpulkan menjadi 6 faktor hambatan yang dihadapi dalam menggunakan uang elektronik M, yaitu: 1) merchant yang bekerjasama dengan uang elektronik $M$ masih terbatas; 2) uang elektronik $M$ tidak dapat digunakan untuk transaksi offline; 3) belum familiar dengan penggunaan uang elektronik dan lebih terbiasa menggunakan metode pembayaran selain uang elektronik (misal: transfer, kartu kredit, dan kartu debit); 4) produk uang elektronik lain lebih menarik; 5) uang elektronik $M$ tidak memiliki versi mobile; 6) top-up dikenakan biaya jaringan ATM antarbank.

\section{Hasil Wawancara}

Pengelola uang elektronik M menyampaikan bahwa tantangan utama yang dihadapi perusahaan dalam mengembangkan uang elektronik adalah dari segi kompetisi dengan produk sejenis. Di Indonesia, ada 20 penerbit uang elektronik yang sudah mendapatkan izin dari Bank Indonesia. Penerbit uang elektronik tersebut di antaranya adalah bank dan perusahaan telekomunikasi yang sudah memiliki basis konsumen yang kuat. Sementara itu, uang elektronik merupakan sistem pembayaran yang masih baru dikenal oleh masyarakat Indonesia. PT XYZ harus dapat bersaing dengan 20 kompetitor produk sejenis untuk memperoleh pelanggan, di mana pasar pengguna uang elektronik belum sepenuhnya terbentuk.

Selain itu, PT XYZ merupakan perusahaan yang pada awalnya bergerak pada bisnis berbentuk B2B (Business-to-business). Dengan adanya pengembangan produk uang elektronik ini, perusahaan harus beradaptasi dengan cepat untuk dapat menjalankan bisnis yang berbentuk B2C (Business-to-customer). Pada perjalanannya, perusahaan menyadari bahwa bisnis uang elektronik sangat berbeda dengan bisnis-bisnis yang sudah dijalankan perusahaan sebelumnya. Bisnis uang elektronik sangat bergantung pada basis pelanggan. Sebagai perusahaan yang selama ini menjalin hubungan bisnis dengan institusi, perlu penyesuaian untuk dapat mendekati konsumen secara langsung. 
TABEL 6

TANTANGAN PT XYZ DALAM IMPLEMENTASI UANG ELEKTRONIK M

\begin{tabular}{|c|c|c|}
\hline No & Hambatan & Tantangan bagi PT. XYZ \\
\hline \multicolumn{3}{|c|}{ Perspektif nasabah } \\
\hline 1 & Mitra yang bekerjasama dengan uang elektronik $\mathrm{M}$ masih terbatas & $\begin{array}{l}\text { Kompetitor produk sejenis telah bekerjasama } \\
\text { dengan mitra yang lebih banyak dan populer }\end{array}$ \\
\hline 2 & $\begin{array}{l}\text { Uang elektronik } \mathrm{M} \text { tidak dapat digunakan untuk transaksi selain di } \\
\text { toko online }\end{array}$ & $\begin{array}{l}\text { Kompetitor produk sejenis telah menyediakan } \\
\text { layanan untuk bertransaksi secara offline }\end{array}$ \\
\hline 3 & $\begin{array}{l}\text { Belum familiar dengan penggunaan uang elektronik dan lebih } \\
\text { terbiasa menggunakan metode pembayaran selain uang elektronik } \\
\text { (misal: transfer, kartu kredit, dan kartu debit) }\end{array}$ & $\begin{array}{l}\text { Produk substitusi seperti kartu kredit atau kartu } \\
\text { debit lebih banyak digunakan masyarakat } \\
\text { dibandingkan uang elektronik. }\end{array}$ \\
\hline 4 & Uang elektronik M tidak memiliki versi mobile & $\begin{array}{l}\text { Kompetitor produk sejenis telah menyediakan } \\
\text { layanan uang elektronik yang dapat diakses secara } \\
\text { mobile }\end{array}$ \\
\hline 5 & $\begin{array}{l}\text { Banyak pilihan produk uang elektronik lain yang lebih memenuhi } \\
\text { kebutuhan transaksi }\end{array}$ & $\begin{array}{l}\text { Kompetitor produk sejenis lebih nyaman digunakan } \\
\text { dibandingkan uang elektronik } \mathrm{M}\end{array}$ \\
\hline 6 & Top up dengan transfer dikenakan biaya transfer antar bank & $\begin{array}{l}\text { Kompetitor produk sejenis memiliki banyak } \\
\text { alternatif metode top up dengan biaya yang } \\
\text { terjangkau }\end{array}$ \\
\hline \multicolumn{3}{|c|}{ Perspektif pengelola } \\
\hline 7 & $\begin{array}{l}\text { PT. XYZ selama ini menjalankan bisnis B2B sementara produk uang } \\
\text { elektronik M memiliki model bisnis B2C. }\end{array}$ & $\begin{array}{l}\text { Kompetitor produk sejenis telah banyak } \\
\text { berpengalaman dalam model bisnis B2C. }\end{array}$ \\
\hline 8 & Kesulitan untuk mengakuisisi pelanggan baru. & $\begin{array}{l}\text { Kompetitor produk sejenis sudah memiliki basis } \\
\text { pelanggan yang kuat }\end{array}$ \\
\hline
\end{tabular}

Pengelola uang elektronik M melihat peluang adanya kerjasama yang dapat dilakukan antar penerbit uang elektronik. Salah satunya adalah menyediakan fasilitas untuk transfer dana antar rekening uang elektronik. Pengelola uang elektronik M memiliki harapan untuk dapat berperan dalam kerjasama antar penerbit uang elektronik dalam memenuhi kebutuhan nasabah.

Berdasarkan hasil wawancara kepada nasabah uang elektronik $\mathrm{M}$, diidentifikasi beberapa tantangan dan hambatan yang dialami dalam menggunakan uang elektronik M. Hambatan pertama yang diidentifikasi adalah bahwa pada umumnya nasabah masih terbiasa menggunakan metode pembayaran transfer, debit, atau kartu kredit. Nasabah uang elektronik $M$ sudah merasa nyaman menggunakan metode pembayaran yang sudah ada sebelum kemunculan uang elektronik. Menurut narasumber yang diwawancarai, kebutuhan transaksi online yang mereka lakukan sudah dapat dipenuhi dengan metode pembayaran selain uang elektronik. Kemunculan uang elektronik tidak dianggap menarik bagi narasumber karena perlu mempelajari cara penggunaannya dan membiasakan diri terhadap hal baru.

Hambatan berikutnya yang dihadapi narasumber adalah biaya isi ulang saldo uang elektronik (top up) yang dirasa mahal. Metode isi ulang uang elektronik M yang disediakan PT XYZ masih terbatas pada metode transfer antar bank atau ke loket uang elektronik M. Loket uang elektronik M hanya ada di satu lokasi saja sehingga tidak fleksibel untuk dijangkau. Sementara, untuk melakukan top-up melalui ATM, nasabah akan dikenakan biaya transfer antar bank. Hal ini menjadi hambatan yang membuat nasabah tidak ingin bertransaksi menggunakan uang elektronik $\mathrm{M}$.
Jenis produk uang elektronik yang dikenal nasabah umumnya adalah uang elektronik berbasis kartu. Hal ini dikarenakan penggunaanya banyak ditemui pada sarana transportasi seperti Transjakarta, CommuterLine, serta Gerbang Tol Elektronik. Responden masih sedikit mengetahui produk uang elektronik yang dapat digunakan untuk berbelanja online. Menurut responden, penggunaan uang elektronik M masih terbatas pada toko online yang menjadi merchant. Responden mengharapkan uang elektronik $\mathrm{M}$ dapat digunakan untuk berbagai jenis pembayaran elektronis, baik secara online maupun offline.

Berdasarkan daftar hambatan penggunaan uang elektronik $\mathrm{M}$ dari sisi nasabah yang diperoleh melalui kuesioner maupun wawancara, dapat diidentifikasi tantangan yang dihadapi PT XYZ untuk mengembangkan bisnis produk uang elektronik M. Terdapat 6 hambatan utama dalam penggunaan uang elektronik $M$ menurut nasabah serta 2 hambatan utama berdasarkan perspektif pengelola. Daftar tantangan yang dihadapi PT XYZ berdasarkan hambatan yang dialami nasabah maupun pengelola dapat dilihat pada Tabel 6 .

\section{Implikasi Penelitian}

\section{Implikasi Terhadap Organisasi}

Hasil penelitian yang telah dilakukan bermanfaat bagi PT XYZ karena memberikan informasi mengenai kondisi terkini dari produk uang elektronik M. Melalui survei yang dilakukan pada nasabah uang elektronik $M$ dapat diketahui persepsi pengguna terhadap produk uang elektronik M. Hasil survei menunjukkan bahwa persepsi pengguna uang elektronik $M$ terhadap ketersediaan infrastruktur dan kenyamanan penggunaan uang elek- 
tronik $\mathrm{M}$ sudah baik. Variabel dalam survei yang memperoleh nilai terendah adalah variabel preferensi penggunaan. Artinya, kecenderungan nasabah untuk memilih produk uang elektronik $\mathrm{M}$ dibandingkan uang elektronik lainnya masih dapat ditingkatkan.

Penelitian ini juga membantu PT XYZ mengidentifikasi tantangan dan hambatan yang dihadapi dalam implementasi produk uang elektronik $M$. Berdasarkan hasil survei dan wawancara, hambatan yang dihadapi penggunaan uang elektronik $\mathrm{M}$ dari sisi nasabah adalah keterbatasan merchant, keterbatasan metode akses, keterbatasan channel transaksi, biaya transaksi, kompetitor produk sejenis, serta faktor sosial budaya yaitu kebiasaan menggunakan metode pembayaran selain uang elektronik. Hambatan uang elektronik $M$ dari sisi pengelola adalah kurangnya pengalaman dalam menjalankan model bisnis B2C serta sulitnya mengakuisisi nasabah baru. Berdasarkan hambatan yang dialami, maka dapat diketahui tantangan yang dihadapi PT XYZ dalam implementasi uang elektronik $\mathrm{M}$ adalah tingkat kompetisi produk sejenis yang tinggi, adanya pengaruh barang substitusi seperti kartu kredit dan debit, serta tingginya ekspektasi nasabah untuk memperoleh layanan uang elektronik yang aman, nyaman, dan terpercaya.

Visi 5 tahunan PT XYZ periode tahun 20142018 adalah membangun sistem pembayaran nasional yang meliputi jasa media transaksi, jasa jaringan transaksi, jasa transaksi pembayaran, dan jasa terminal transaksi. Produk uang elektronik M merupakan salah satu layanan PT XYZ yang diharapkan mendukung visi tersebut sebagai jasa media transaksi (issuing services). Namun, saat ini pencapaian bisnis dari produk uang elektronik $\mathrm{M}$ masih jauh dari target yang ditentukan PT XYZ. Berdasarkan hasil penelitian diketahui bahwa tantangan utama yang dihadapi PT XYZ adalah jumlah kompetitor yang banyak, ekspektasi nasbah yang tinggi, serta adanya kompetisi dengan produk sejenis. Selain itu, PT XYZ sebagai perusahaan yang awalnya menjalankan bisnis $\mathrm{B} 2 \mathrm{~B}$, harus menjalankan bisnis B2C sebagai konsekuensi diluncurkannya produk uang elektronik M. Hal ini telah menjadi hambatan yang dihadapi PT XYZ sehingga target bisnis yang ditentukan sebelumnya tidak tercapai. Pencapaian target dalam imple-mentasi produk uang elektronik M merupakan salah satu penentu keberhasilan visi PT XYZ untuk membangun sistem pembayaran nasional.

\section{Implikasi Terhadap Teori}

Hasil analisis dalam penelitian ini memiliki keterkaitan dengan hasil penelitian yang sudah ada sebelumnya. Faktor sosial budaya sebagai hambatan dalam pengembangan e-commerce juga telah dikemukakan oleh Efendioglu [14] dan Kumaga
[4]. Penelitian Efendioglu [14] menyatakan bahwa faktor sosial budaya seperti kebiasaan penggunaan metode pembayaran yang sebelumnya adalah salah satu hambatan yang dapat menjadi tantangan utama dalam pengembangan e-commerce di negara berkembang. Selain itu Efendioglu [14] juga menyatakan biaya transaksi adalah juga salah satu tantangan yang dihadapi dalam pengembangan $e$ commerce.

Adanya kompetitor produk sejenis sebagai tantangan dalam pengembangan e-payment juga telah dikemukakan oleh Sahut [9]. Tantangan utama dalam pengembangan e-payment dapat dikategorikan menjadi 3, yaitu tantangan dalam hal teknologi, tantangan dalam pemasaran, serta tantangan dalam kompetisi dengan produk sejenis. Menurut wawancara dengan pengelola uang elektronik $\mathrm{M}$, tantangan utama yang mereka hadapi adalah kompetisi dengan produk sejenis. Tantangan berikutnya adalah pemasaran produk uang elektronik M. Adanya tantangan pada pemasaran produk uang elektronik juga ditunjukkan dari kuesioner maupun wawancara terhadap nasabah. Hal ini dapat dilihat dari keterbatasan merchant, keterbatasan channel pembayaran, dan keterbatasan metode akses.

\section{Kesimpulan}

Penelitian ini telah menilai kondisi implementasi produk uang elektronik M dari periode tahun 2012 sampai 2014. Penilaian kondisi implementasi dilakukan dengan metode survei dan wawancara. Berdasarkan hasil survei, diperoleh kesimpulan bahwa ketersediaan infrastruktur, tingkat kenyamanan, dan penerimaan pengguna terhadap uang elektronik M sudah baik. Namun, preferensi pengguna untuk memilih produk uang elektronik $\mathrm{M}$ dibandingkan produk uang elektronik lainnya masih cukup baik. Berdasarkan hasil wawancara, diketahui bahwa jumlah nasabah dan jumlah merchant yang diperoleh produk uang elektronik M sampai saat ini belum mencapai target yang diharapkan. Target nasabah pada tahun 2014 adalah 142.616 sementara jumlah nasabah pada saat penelitian dilakukan adalah 1.776. Target jumlah merchant pada tahun 2014 adalah 20 merchant sementara jumlah merchant yang tergabung pada saat penelitian dilakukan adalah 11 merchant.

Selain itu, penelitian ini telah mengidentifikasi tantangan dan hambatan implementasi uang elektronik M berdasarkan data yang dikumpulkan dari nasabah maupun pengelola uang elektronik $\mathrm{M}$. Berdasarkan hasil survei dan wawancara kepada nasabah uang elektronik $\mathrm{M}$ diperoleh faktor-faktor yang menjadi tantangan dan hambatan uang elektronik M. Hambatan yang dialami nasabah dalam menggunakan uang elektronik $\mathrm{M}$ adalah keter- 
batasan merchant, keterbatasan metode transaksi, biaya transaksi yang mahal, banyaknya pilihan produk sejenis, serta faktor sosial budaya yaitu kebiasaan menggunakan metode pembayaran selain uang elektronik. Hambatan yang dialami oleh pengelola uang elektronik $\mathrm{M}$ adalah kurangnya pengalaman menjalankan model bisnis B2C, serta sulitnya mengakuisisi pelanggan baru. Tantangan yang dihadapi oleh PT XYZ dalam implementasi produk uang elektronik $\mathrm{M}$ adalah tingkat kompetisi produk sejenis yang tinggi, adanya pengaruh barang substitusi serta tingginya ekspektasi nasabah untuk memperoleh layanan uang elektronik yang aman, nyaman, dan terpercaya.

Keterbatasan penelitian ini adalah tantangan dan hambatan produk uang elektronik $M$ dilihat hanya dari sisi pengguna serta pengelola. Penelitian belum melihat faktor-faktor yang menjadi tantangan dan hambatan produk uang elektronik $\mathrm{M}$ dilihat dari sisi merchant atau toko. Selain itu, kelompok responden yang belum pernah bertransaksi menggunakan uang elektronik $M$ tidak seimbang perbandingannya dengan kelompok responden yang pernah menggunakan uang elektronik M. Data demografi yang diperoleh melalui kuesioner tidak meliputi jenis pembayaran selain uang elektronik yang lebih disukai oleh responden sehingga tidak diketahui persentase pemakaian metode-metode pembayaran yang digunakan responden. Terakhir, penelitian ini tidak memberikan rekomendasi lebih lanjut terkait strategi yang harus dilakukan perusahaan terkait tantangan dan hambatan yang ditemui.

Saran yang dapat diberikan terhadap PT XYZ dalam pengembangan uang elektronik $M$ yaitu memperbanyak kerjasama dengan merchant, terutama yang memiliki basis pelanggan yang kuat. Kerjasama dengan merchant yang basis pelanggannya kuat memperbesar kemungkinan pertumbuhan jumlah nasabah uang elektronik M. Selain itu PT XYZ juga perlu memperkecil biaya transaksi yang dikenakan kepada nasabah, contohnya biaya top up saldo. Pengembangan fitur untuk bertransaksi dengan merchant secara offline juga perlu dilakukan, sehingga uang elektronik $M$ tidak hanya dapat digunakan secara online.

Saran yang dapat diberikan untuk penelitian selanjutnya adalah melakukan pengukuran terhadap metode pembayaran online selain uang elektronik yang paling sering digunakan oleh nasabah, misalnya metode transfer, kartu debit, atau kartu kredit. Selain itu perlu juga dilakukan survei dengan perbandingan yang lebih seimbang antara responden yang belum pernah bertransaksi menggunakan uang elektronik $\mathrm{M}$ dan responden yang sudah pernah bertransaksi menggunakan uang elektronik M. Survei atau wawancara kepada merchant mengenai hambatan yang dialami selama be- kerjasama dengan uang elektronik $M$ juga akan bermanfaat untuk memperkaya hasil penelitian. Penyusunan rekomendasi strategi bisnis uang elektronik M terkait tantangan dan hambatan yang telah diidentifikasi juga dapat dilakukan untuk memberikan manfaat yang lebih besar terhadap organisasi.

\section{Referensi}

[1] "Bank Indonesia Official Web Site - Bank Sentral Republik Indonesia". Bi.go.id. N.p., 2014.

[2] "Bank Indonesia Official Web Site - Bank Sentral Republik Indonesia". Bi.go.id. N.p., 2013.

[3] "Bank Indonesia Official Web Site - Bank Sentral Republik Indonesia". Bi.go.id. N.p., 2015.

[4] D. Kumaga, "The challenges of implementting Electronic Payment Systems - The Case of Ghana's E-zwich Payment System," Blekinge Tekniska Hogskola, 2010.

[5] E. Agyeiwaah, G. Afua, S. Anane, K. O. Appiah, and J. Opoku-Ware, "Challenges of E-Zwich at Ghana Commercial Bank: do the views of users differ to those of non-users?," African J. Hosp. Tour. Leis., vol. 3, no. 2, 2014.

[6] I. Haruna, "Challenges of Electronic Payment Systems in Ghana: The Case of e-ZWICH," Am. J. Bus. Manag., vol. 1, no. 3, pp. 87-95, 2012.

[7] E. Turban, Electronic Commerce: A Managerial Perspective. Prentice Hall, 2008.

[8] S. Sumanjeet, "Emergence of Payment Systems in the Age of Electronic Commerce: The State of Art," Global Journal of International Business Research., vol. 2, no. 2, 2009.

[9] J.-M. Sahut, "Internet Payment and Banks," International Journal of Business., vol. 13, no. 4, 2008.

[10] Fung, Ben, Miguel Molico, and Gerald Stuber. Electronic money and payments: Recent developments and issues. No. 2014-2. Bank of Canada Discussion Paper, 2014.

[11] Bank Indonesia, "Peraturan Bank Indonesia Nomor: 11/12/PBI/2009 ," Bank Indonesia, Regulation 2009.

[12] P. N. Dao, "Implementation of E-banking in Vietnam: Motivations and challenges - Case Company A," Lahti University of Applied Sciences, 2014.

[13] J. M. Sahut and M. Galuszewska, "Electronic payment market: a non-optimal equilibrium,"2004 International Symposium on Appli-cations and the Internet Workshops. 2004 Workshops., 2004, pp. 3-8. 
48 Jurnal Sistem Informasi (Journal of Information Systems), Volume 13, Issue 1, April 2017

[14] A. M. Efendioglu, V. F. Yip, and W. L. Murray, "E-commerce in Developing Coun- tries: Issues and Influences," San Fransisco: University of San Francisco Press, 2004. 